\title{
COURTSHIP AND MATING BEHAVIOUR IN EBALIA TUBEROSA (PENNANT) (DECAPODA, BRACHYURA, LEUCOSIIDAE)
}

\section{BY}

\author{
PATRICK J. SCHEMBRI \\ 72 Brared Street, B'Kara, Malta
}

\section{INTRODUCTION}

There is a dearth of information on any aspect of the biology of crabs of the family Leucosiidae. Knowledge of the sexual behaviour of members of this family is limited to the description of the courtship and mating behaviour of Philyra scabriuscula (Fabricius) by Naidu (1954) and a brief mention of the courtship behaviour of Philyra laevis (Bell) by Hale (1926).

During the course of studies on the general biology of Ebalia tuberasa (Pennant, 1777), courtship and mating behaviour were observed in individuals kept in aquaria in the laboratory and are described in this paper.

\section{MATERIAL AND METHODS}

E. tuberosa was collected by dredging off Farland Point, Isle of Cumbrae, Scotland, at depths of about $44 \mathrm{~m}$. In the laboratory the crabs were kept on their natural substratum in aquaria supplied with recirculating seawater. The crabs were fed once every 3 or 4 days on scallops and on polychaete worms. Courtship and mating were studied by direct observation and by time-lapse photography. Sexual behaviour in over 60 individuals was observed over a period of two years.

\section{RESULTS}

General observations. - E. tuberosa live on subtidal coarse substrata in which they burrow. No permanent burrows are constructed but the crabs simply embed themselves in the sediment leaving only the anteriormost tip of the carapace, bearing the eyes, antennules and openings of the inhalant and exhalant respiratory channels, visible above the level of the sediment (Schembri, 1981). The crabs normally remain buried in the substratum during daytime but become active and wander about on the surface of the sediment during darkness (Schembri, unpubl.).

In the laboratory $E$. tuberosa was observed to mate during the months of October and November and occasionally, at other times of the year. In monthly 
collections of $E$. tuberosa from Farland Point over the period March 1977 to January 1979 , crabs in copula were found in the dredge samples only during November (Schembri, 1982).

Courtship (fig. 1a, b) and mating (fig. 1e, d). - The male is the active partner and seeks out the female. In pre-mating behaviour, the male climbs on top of the female or half-buries himself in front of her and embraces her with his chelae. The male then positions himself in front of and beneath the female with his ventral side opposed to hers and maintains this position by clasping the female with his chelipeds and by interlocking his walking legs with those of his mate. The female may assist the male to hold this position by embracing him with her chelipeds. The female then exposes her sexual openings by extending the abdomen whereupon the male inserts his abdomen into the abdominosternal chamber of the female and pushes the tips of his 1st pleopods inside the vulvae of the female. The female apertures lie on two small raised humps one on either side of the midventral line on the 6 th thoracic sternites. These raised humps probably serve as guides for the male's pleopods.

The copulating pair may partly bury themselves in the sediment or may remain on the surface. The crabs may remain in copula for up to 9 hours but the actual duration of sperm transfer is not known. After mating the crabs may either separate immediately or may remain quiescent near each other for a time before separating.

\section{DISGUSSION}

Sexual behaviour in the Brachyura has been reviewed by Hartnoll (1969) and more recently by Hazlett (1975). Hartnoll (1969) has divided crabs into two groups, those which mate when the female is 'hard' and those which mate when the female is still 'soft' following ecdysis. E. tuberosa belongs to the former group as does Philyra scabriuscula (see Naidu, 1954) the only other leucosiid for which data are available. The sexual behaviour of $E$. tuberosa fits in very well with the typical behaviour of 'hard'-mating crabs as described by Hartnoll (1969).

In $E$. tuberosa copulation is preceded by a phase of pre-copulatory behaviour during which there is an apparent exchange of signals between the interacting crabs and which probably serve to communicate the readiness to mate. In Ebalia these signals are mainly tactile although visual and chemical stimuli may also be important.

The pre-copulatory behaviour of Philyra laevis is very different from that in $E$. tuberosa. In $P$. laevis the male performs a 'dance' in front of the female to which the latter responds by retracting the pereiopods and becoming quiescent. The male then seizes the female in one of his chelae and carries her off, presumably to mate (Hale, 1926). Carrying of the female by the male prior to copulation is known also from a few other crabs (e.g. Carcinus maenas (L.) and Cancer magister Dana, see Schöne, 1968; Corystes cassivelaunus (Pennant), see Hartnoll, 1968). 
The sexual behaviour of Philyra scabriuscula is different still from that of both $E$. tuberosa and its congener $P$. laevis. In $P$. scabriuscula the male holds the female beneath him, hooking his first pair of walking legs onto her chelae and walking legs. After a variable length of time the female responds by extending her abdomen whereupon the male moves "with great rapidity" to face the female and copulates. Copulation lasts a few seconds only (Naidu, 1954).

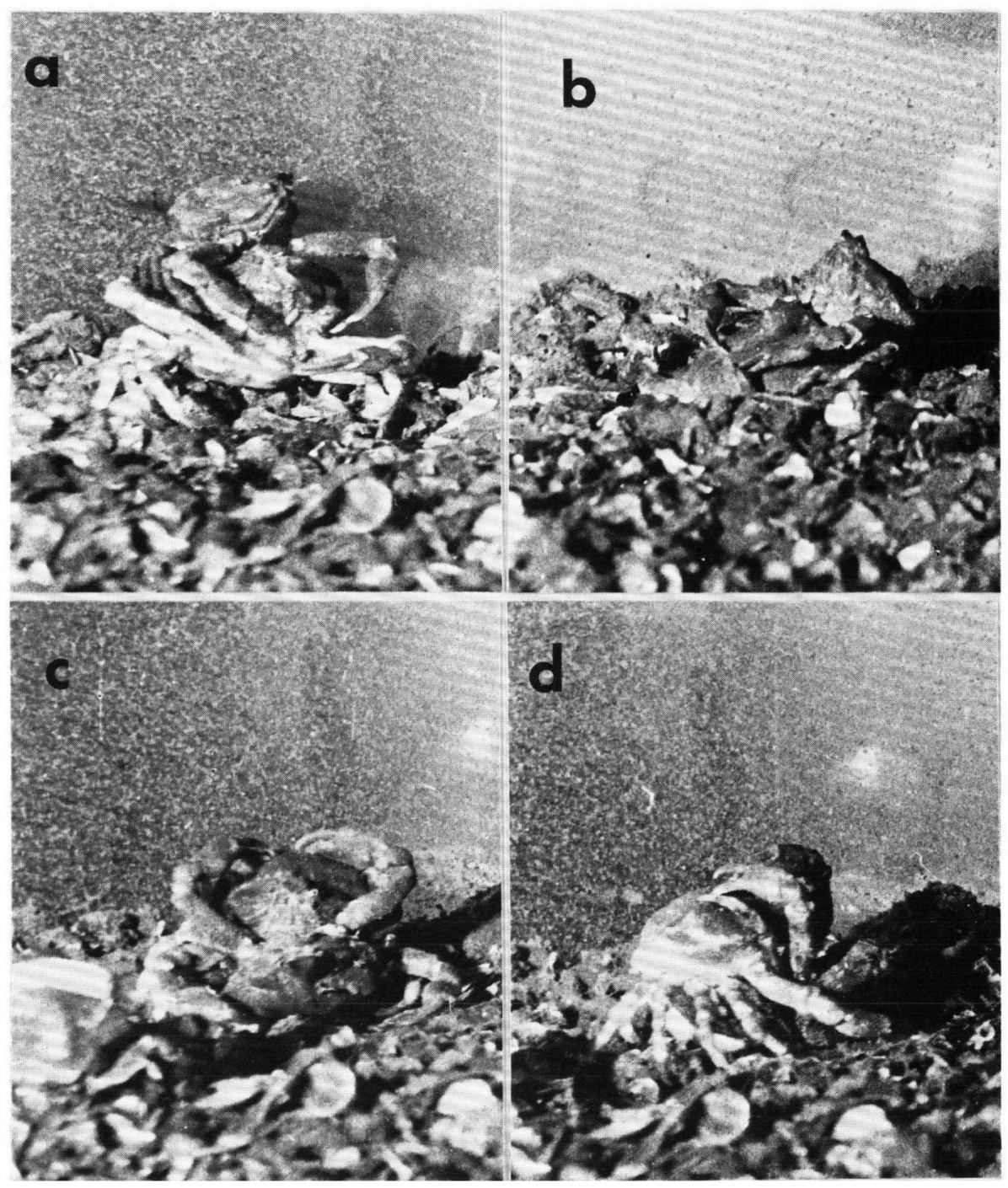

Fig. 1. Courtship (a, b) and mating (c, d) in Ebalia tuberosa (Pennant); photographs are selected frames from a complete time-lapse sequence of mating in a single pair of crabs; $a$, the male is on top of the female; $b$, the male is half-buried in front of the female which is nearest the camera; $c$, $\mathrm{d}$, the male is beneath the female. The female crab is about $15 \mathrm{~mm}$ in width. 
Schöne (1968) has pointed out that in aquatic crabs courtship behaviour involves predominantly tactile signs, and perhaps also chemical stimuli, while in semi-terrestrial crabs courtship displays are mainly visual. This is presumably due to the different environmental conditions on land or shallow water and in the deep sea. This may be one of the reasons for the differences in the sexual behaviour of $E$. tuberosa and $P$. laevis. The former lives in deep water (most animals were collected from depths greater than $40 \mathrm{~m}$ ) and has a predominantly tactile pre-copulatory behaviour. $P$. laevis on the other hand lives in very shallow water (depths of a few $\mathrm{cm}$ only; Hale, 1926) and pre-copulatory behaviour in this species is mainly visual, the 'dance' of the male in front of the female being reminiscent of the displays of $U c a$ and other ocypodids (Schöne, 1968; Wright, 1968; Crane, 1975).

Mating in $P$. scabriuscula is unusual in that it appears to take place while the female is carrying eggs. In $E$. tuberosa mating between a male and an ovigerous female was also observed, although on a single occasion only. Copulation with females carrying eggs is a common phenomenon in hermit crabs (see Hazlett, 1975 and references therein) but is rare in brachyurans. In this group, apart from the Leucosiidae, this behaviour is known only in some majiids (e.g. Microphrys bicornutus (Latreille), see Hartnoll, 1965; Libinia emarginata Leach, see Hinsch, 1968; Pleistacantha moseleyi (Miers), see Berry \& Hartnoll, 1970 and Maja squinado (Herbst), see Števčić, 1967). The significance of this behaviour is not known at present.

\section{ACKNOWLEDGEMENTS}

I am grateful to Professor J. A. Allen for his interest in this work and for providing the necessary facilities. I thank Dr. R. J. A. Atkinson for the loan of time-lapse photography equipment. This work was carried out at the University Marine Biological Station, Millport, Isle of Cumbrae, Scotland, during the tenure of a Commonwealth Scholarship awarded by the Association of Commonwealth Universities.

\section{ZUSAMMENFASSUNG}

Balz- und Kopulationsverhalten von Ebalia luberosa wurden im Labor beobachtet. Das Weibchen ist "gehärtet" bei der Kopulation. Das Männchen ist der aktive Partner und sucht sich ein Weibchen aus. Die Krabben kopulieren nach einer Periode präkopulatorischer Aktivität, während der Signale ausgetauscht werden. Sie können bis zu 9 Stunden in Kopulationsstellung verharren. Im Freiland finden Fortpflanzungsaktivitäten wahrscheinlich nur einmal und zwar im November statt. Das Balz- und Kopulationsverhalten von E. tuberosa wird mit den anderer Leucosiiden verglichen.

\section{REFERENCES}

Berry, P. F. \& R. G. Hartnoli, 1970. Mating in captivity of the spider crab Pleistacantha moseleyi (Miers) (Decapoda, Majidae). Crustaceana, 19: 214-215.

Crane, J., 1975. Fiddler crabs of the world (Ocypodidae: genus Uca): i-xxiii, 1-736. (Princeton University Press, New Jersey). 
Hale, H. M., 1926. Habits of the smooth pebble crab (Philyra laevis Bell). South Australian Naturalist, Adelaide, 7: 67-69.

Hartnoll, R. G., 1965. The biology of spider crabs: a comparison of British and Jamaican species. Crustaceana, 9: 1-16.

-, 1968. Reproduction in the burrowing crab, Corystes cassivelaunus (Pennant, 1777) (Decapoda, Brachyura). Crustaceana, 15: 165-170.

- -, 1969. Mating in the Brachyura. Crustaceana, 16: 161-181.

Hazlett, B. A., 1975. Ethological analyses of reproductive behaviour in marine Crustacea. Pubbl. Staz. zool. Napoli, 39 (suppl.): 677-695.

Hinsch, G. W., 1968. Reproductive behaviour in the spider crab, Libinia emarginata (L.). Biol. Bull. mar. biol. Lab., Woods Hole, 135: 273-278.

Naidu, K. G. R. B., 1954. A note on the courtship in the sand crab (Philyra scabriuscula (Fabricius)). Journ. Bombay nat. Hist. Soc., 52: 640-641.

Schembri, P. J., unpublished. Aspects of the biology, behaviour and functional morphology of the crab Ebalia tuberosa (Pennant), ix +194 pp (Ph.D. thesis, 1980, University of Glasgow).

- , 1981. Substratum preferences, burrowing and righting in Ebalia tuberosa (Pennant) (Crustacea: Decapoda: Leucosiidae). Mar. Behav. Physiol., 8: 149-161.

-, 1982 . The biology of a population of Ebalia tuberosa (Crustacea: Decapoda: Leucosiidae) from the Clyde Sea area. Journ. mar. biol. Assoc. U.K., 62: 101-115.

Schöne, H., 1968. Agonistic and sexual display in aquatic and semi-terrestrial brachyuran crabs. American Zool., 8: 641-654.

Števčić, Z., 1967. A short outline of the biology of the spinous spider crab (Maja squinado). Bull. Sci. Cons. Acad. RSF Yougoslavie, (A, Sci. Natur. Tech. Med.) 12: 313-314.

Wright, H. O., 1968. Visual displays in brachyuran crabs: Field and laboratory studies. American Zool., 8: 655-665. 